\begin{tabular}{|c|c|}
\hline \multirow[t]{2}{*}{ (2) } & Jurnal Penelitian Pendidikan IPA (JPPIPA) \\
\hline & P-ISSN : 2460-2582, E-ISSN : 2407-795X \\
\hline & : Lt. 1 Gedung B FKIP Universitas Mataram \\
\hline & : (0370) 634918 \\
\hline $8 \%$ & : magipa@unram.ac.id \\
\hline & : http://jppipa.unram.ac.id/index.php/jppipa/index \\
\hline
\end{tabular}

\title{
PENGEMBANGAN INSTRUMEN MISKONSEPSI KIMIA PADA KONSEP STRUKTUR ATOM
}

\author{
Mursadam $^{1)}$ Wildan $^{2)}$, Agus Ramdani ${ }^{3)}$ \\ Program Studi Magister Pendidikan IPA, Universitas Mataram ${ }^{123}$ \\ Email: nurulhilmi89suela@gmail.com
}

\begin{tabular}{|c|c|}
\hline Key Words & Abstract \\
\hline $\begin{array}{l}\text { Instrument of } \\
\text { chemistry } \\
\text { conception, } \\
\text { Atom } \\
\text { structure }\end{array}$ & $\begin{array}{l}\text { The research is aimed producing the instrument of chemistry } \\
\text { misconception at the atom structure concept as the instrument for } \\
\text { categorizing the student's misconception. This research is designed as } \\
\text { research and development in according with Borg and Gall. The validity } \\
\text { test of the instruments include validity of cuntructions, validity of } \\
\text { content, validity of psychometrics and the legibility of the instrument. } \\
\text { The research result showed that each individual students are } \\
\text { categorized as fair with the average of } 60,38 \% \text {, the misconception of } \\
\text { students is categorized a also fair in concept of electronic configuration } \\
(53,53 \%) \text {, in sub-skin (55,54\%), in energy level }(59,92 \%) \text { and in those } \\
\text { that is categorized high is in the concept of orbital }(66,66 \%) \text {. }\end{array}$ \\
\hline Kata Kunci & Abstrak \\
\hline $\begin{array}{l}\text { Instrumen } \\
\text { miskonsepsi } \\
\text { kimia, } \\
\text { Struktur atom }\end{array}$ & $\begin{array}{l}\text { Penelitian ini bertujuan untuk menghasilkan instrumen miskonsepsi } \\
\text { kimia pada konsep struktur atom sebagai instrumen untuk } \\
\text { mengkategorikan miskonsepsi siswa. Penelitian ini menggunakan desain } \\
\text { Penelitian dan Pengembangan (Research and Development) menurut } \\
\text { Borg and Gall. Uji validitas instrumen miskonsepsi kimia meliputi } \\
\text { validitas konstruk, validitas isi, validitas psikometrik dan keterbacaan } \\
\text { instrumen. Hasil penelitian menunjukkan bahwa kategori miskonsepsi } \\
\text { siswa tiap individu berada pada kategori sedang dengan rata-rata } \\
58,97 \% \text {, kategori miskonsepsi siswa tiap konsep berada pada kategori } \\
\text { sedang untuk konsep konfigurasi elektron (53,53\%), sub kulit }(55,04 \%) \text {, } \\
\text { tingkat energi }(59,92 \%) \text { dan kategori tinggi hanya terdapat pada konsep } \\
\text { orbital }(66,66 \%) \text {. }\end{array}$ \\
\hline
\end{tabular}

PENDAHULUAN

Setiap peserta didik memiliki prakonsepsi yang dibawa sebagai pengetahuan. Demikian juga setiap peserta didik dapat memiliki konsepsi yang berbeda-beda terhadap suatu konsep. Setiap peserta didik senantiasa aktif membangun struktur kognitifnya berdasarkan pemilihan informasi yang tersedia sesuai dengan keinginannya.
Ketika mereka berusaha membangun struktur kognitif dengan memilih informasi yang ada, baik informasi dari guru, buku atau lingkungan, kemungkinan ada kesalahan dalam mengaitkan keduanya. Prakonsepsi dan konsepsi yang benar dapat menjadi salah ketika ia membangun struktur kognitif baru berdasarkan masukan informasi yang salah, atau sebaliknya. Semuanya itu dapat 
menjadi penyebab terjadinya miskonsepsi pada diri peserta didik (Salirawati \& Wiyarsi, 2011).

Miskonsepsi ini dapat muncul pada diri siswa berasal dari pengalaman seharihari ketika berinteraksi dengan alam sekitarnya. Sebelum mempelajari fisika, semua siswa sudah mempunyai pengalaman dengan peristiwa-peristiwa kimia, misalnya kesetimbangan kimia, koloid, laju reaksi, dan lain-lain. Dengan pengalaman itu maka dibenak para siswa sudah terbentuk suatu intuisi dan teori siswa mengenai peristiwa-peristiwa kimia tersebut, yang sudah tentu intuisi dan teori yang terbentuk tersebut belum tentu benar. Jika intuisi yang tebentuk tersebut salah, biasanya akan sulit sekali untuk diperbaiki, karena tanpa disengaja telah secara konsisten konsep kimia yang salah tersebut menjadi pegangan hidupnya. Adanya miskonsepsi ini jelas akan sangat menghambat pada proses penerimaan dan asimilasi pengetahuan-pengetahuan baru dalam diri siswa, sehingga akan menghalangi keberhasilan siswa dalam proses belajar lebih lanjut (Klammer, 1998 dalam Yuyu R, 2005). Hal Ini merupakan masalah besar dalam pengajaran kimia yang tidak bisa dibiarkan. Seiring dengan tumbuhnya kesadaran akan hal tersebut, maka berbagai upaya untuk menanggulangi masalah miskonsepsi ini terus dikembangkan, meskipun hasilnya belum begitu mendapatkan hasil yang memuaskan.

Sebelum lebih jauh membicarakan tentang upaya penanggulangan miskonsepsi, sebenarnya terdapat persoalan yang lebih mendasar dan sangat urgen dalam masalah miskonsepsi ini, yaitu masalah pengidentifikasian terjadinya miskonsepsi. Hingga saat ini masih terdapat kesulitan dalam membedakan antara siswa-siswa yang miskonsepsi dan yang tidak tahu konsep. Tanpa dapat membedakan diantara keduanya, akan sulit untuk menentukan langkah penanggulangannya, sebab cara penanggulangan untuk siswa yang mengalami miskonsepsi akan berbeda dengan siswa yang tidak tahu konsep. Kesalahan pengidentifikasian akan menyebabkan kesalahan dalam cara penanggulangannya, dan hasilnya pun tidak akan memuaskan. Karena itu sebelum melangkah lebih jauh pada upaya penanggulangannya, terlebih dahulu para pengajar harus memiliki pengetahuan dan kemampuan mengidentifikasi miskonsepsi secara tepat, yang setiap saat dapat digunakan pada proses belajar mengajarnya (Yuyu R, 2005).

Miskonsepsi dapat dipandang sebagai suatu konsepsi atau struktur kognitif yang melekat dengan kuat dan stabil dibenak siswa yang sebenarnya menyimpang dari konsepsi yang dikemukakan para ahli, yang dapat menyesatkan para siswa dalam memahami fenomena alamiah dan melakukan eksplanasi ilmiah (David Hammer, 1996 dalam Yuyu R, 2005). Memahami konsep kimia dalam pembelajaran kimia merupakan hal sangat penting. Pada kenyataannya, peserta didik sering mengalami kesulitan dalam memahami berbagai konsep kimia. Pemahaman konsep kimia oleh peserta didik yang tidak sesuai dengan konsep kimia yang benar menurut para ahli kimia, disebut sebagai miskonsepsi kimia (Suparno, 2005 dalam Yuyu R 2005). Akibat lebih jauh terjadinya miskonsepsi kimia adalah hasil belajar kimia peserta didik yang rendah

Konsep-konsep pada kajian struktur atom tergolong konsep yang sering dipahami miskonsepsi oleh sejumlah besar siswa (Park, 2006; Al-Balushi et al, 2012). Topik struktur atom merupakan salah satu topik kimia yang kaya dengan entitas abstrak, sehingga berpeluang besar dipahami miskonsepsi oleh siswa. Perbaikan miskonsepsi siswa merupakan upaya urgen, karena jika tidak dilakukan siswa akan mengalami kesulitan-kesulitan lanjutan, seperti kegagalan memahami konsep yang lain, serta memperoleh kebermaknaan dalam belajar (Dahar, 2011). Upaya perbaikan miskonsepsi siswa 
SMA pada sejumlah konsep kimia melalui program remedial teaching berbasis strategi conseptual change. Program remedial teaching yang dilaksanakan secara klasikal ini masih belum memberikan hasil yang maksimal karena belum memberikan perhatian kepada karakteristik individual siswa yang mengalami miskonsepsi kimia yang resisten.

Sebagai ilustrasi, ketika prakonsepsi siswa tentang pergerakan matahari salah (miskonsepsi) sangat dimungkinkan siswa gagal untuk memahami teks tentang tata surya secara akurat karena siswa tidak dapat mendamaikan informasi yang tercantum dalam teks dengan latar belakang pengetahuan yang sudah ada sebelumnya di dalam struktur kognitif siswa, pengetahuan yang diperoleh siswa dari pengalaman persepsi sehari-hari. Penggunaan prakonsepsi yang sudah ada sebelumnya (misalnya, latar belakang pengetahuan yang salah) dalam memahami wacana dapat menimbulkan terbangunnya sebuah model mental yang tidak akurat, yang berbeda dengan model ilmiah yang dimaksudkan oleh penulis teks (Chi et al., 1994). Prakonsepsi seperti itu dapat menimbulkan apa yang disebut Horton (2004) sebagai asimilasi dari informasi yang masuk ke struktur pengetahuan yang sudah ada sebelumnya, bukan akomodasi struktur pengetahuan.

Saat ini belum tersedia instrumen miskonsepsi kimia pada struktur atom yang dapat mengungkap kategori miskonsepsi siswa. Untuk itu penting untuk dikembangkan instrumen itu melalui suatu penelitian. Perbaikan siswa yang mengalami miskonsepsi adalah upaya urgen, karena jika tidak dilakukan siswa akan mengalami kesulitan-kesulitan lanjutan, seperti kegagalan memahami konsep yang lain, serta memperoleh kebermaknaan dalam belajar (Dahar, 2011).

Langkah awal yang harus dilakukan untuk memperbaiki konsepsi siswa yang salah atau miskonsepsi adalah dengan melakukan pengkategorian miskonsepsi siswa. Faktor penyebab miskonsepsi dapat bersumber pada guru, buku (bahan ajar), metode/model/strategi pembelajaran, dan faktor internal siswa (Suparno, 2005). Faktor penyebab miskonsepsi yang bersumber pada internal siswa di antaranya gaya belajar siswa (Abosalem, 2013; Sen \& Yilmaz, 2012), model mental yang dimiliki siswa dan tingkat konflik kognitif siswa saat dilakukan conceptual change (Kang et al., 2004; Lee et al., 2003).

Konsep struktur atom dipilih sebagai konsep target karena terdapat bukti konsep ini adalah salah satu konsep kimia yang sering dipahami secara miskonsepsi oleh siswa (Park, 2006; Al-Balushi et al, 2012). Topik struktur atom merupakan salah satu topik kimia yang kaya dengan entitas abstrak, sehingga berpeluang besar dipahami miskonsepsi oleh siswa.

\section{METODOLOGI}

Penelitian ini merupakan penelitian pengembangan (Research and Development). Peneliti telah mengembangkan instrumen miskonsepsi kimia pada konsep strukrur atom. Masingmasing komponen instrumen akan diuji apakah memenuhi syarat dari aspek validitas konstruk, validitas isi, validitas psikometrik (validitas butir, reliabilitas, indeks kesukaran, dan daya beda), dan keterbacaan.

Model pengembangan dalam penelitian ini menggunakan model prosedural yang bersifat deskriptif. Model ini menggariskan langkah-langkah umum yang harus diikuti untuk menghasilkan produk, bahan material atau rancangan. Siklus penelitian dan pengembangan menurut Borg \& Gall (dalam Punaji, 2015) adalah sebagai berikut: (1) penelitian dan pengumpulan informasi awal, (2) perencanaan, (3) pengembangan format produk awal, (4) revisi produk, (5) uji lapangan, (7) revisi produk akhir, (8) desiminasi dan implementasi.

Variabel dalam penelitian ini adalah: validitas konstruk, validitas isi, valisitas 
psikometrik, syarat keterbacaan dan kategori miskonsepsi. Subyek penelitian untuk validitas konstruk dan validitas isi adalah 3 (tiga) validator. Subjek penelitian untuk validitas psikometrik adalah 125 orang siswa kelas XII MIPA SMAN 5 Kota Bima. Siswa kelas XII MIPA dipilih sebagai subyek penelitian karena siswa ini telah mengalami pembelajaran struktur Tabel 1. Teknik Pengumpulan Data dan Instrumen Penelitian.

\begin{tabular}{|c|c|c|c|}
\hline No. & Variabel Penelitian & $\begin{array}{c}\text { Teknik Pengumpulan } \\
\text { Data }\end{array}$ & Instrumen Penelitian \\
\hline 1 & Validitas Konstruk & $\begin{array}{l}\text { Expert Judgement berupa } \\
\text { penilaian tertutup }\end{array}$ & $\begin{array}{l}\text { Lembar validasi (bentuk check list). } \\
\text { Naskah instrumen miskonsepsi kimia } \\
\text { dilengkapi kisi-kisi }\end{array}$ \\
\hline 2 & Validitas Isi & $\begin{array}{l}\text { Expert Judgement berupa } \\
\text { penilaian terbuka/catatan } \\
\text { editing yang diberikan oleh } \\
\text { ahli }\end{array}$ & $\begin{array}{l}\text { Lembar telaah } \\
\text { naskah instrumen miskonsepsi kimia } \\
\text { dilengkapi kisi-kisi }\end{array}$ \\
\hline 3 & $\begin{array}{l}\text { Validitas } \\
\text { Psikometrik }\end{array}$ & Tes tertulis kepada siswa & $\begin{array}{l}\text { Naskah instrumen miskonsepsi kimia } \\
\text { dilengkapi lembar jawaban }\end{array}$ \\
\hline 4 & Keterbacaan & Pengisian angket siswa & $\begin{array}{l}\text { Angket keterbacaan siswa bentuk } \\
\text { setengah terbuka. } \\
\text { Naskah instrumen miskonsepsi kimia }\end{array}$ \\
\hline 5 & $\begin{array}{c}\text { Kategori } \\
\text { Miskonsepsi }\end{array}$ & Tes tertulis kepada siswa & $\begin{array}{l}\text { Naskah instrumen miskonsepsi kimia } \\
\text { dilengkapi lembar jawaban }\end{array}$ \\
\hline
\end{tabular}

Teknik analisis data dalam penelitian ini secara ringkas dibuat dalam bentuk atom. Subjek penelitian untuk pengkategorian miskonsepsi adalah 125 orang siswa kelas XI MIPA SMAN 5 Kota Bima.

Teknik pengumpulan data dan instrumen penelitian secara ringkas dibuat dalam bentuk matriks sebagaimana dalam Tabel 1.

Tabel 2. Teknik Analisis Data

\begin{tabular}{cll}
\hline No. & \multicolumn{1}{c}{ Variabel Penelitian } & \multicolumn{1}{c}{ Pendekatan/Teknik Analisis Data } \\
\hline 1 & Validitas Konstruk & Analisis rasional \\
\hline 2 & Validitas Isi & Analisis rasional \\
\hline 3 & Validitas Psikometrik & $\begin{array}{l}\text { Korelasi skor item-total dengan formula product- } \\
\text { moment } \text { Pearson }\end{array}$ \\
\hline 4 & Keterbacaan & Menggunakan Gunning Fog Index \\
\hline 5 & Kategori Miskonsepsi & Menggunakan CRI (Certainty of Response Index), \\
\hline
\end{tabular}

Persentasi skor untuk validitas konstruksi diinterpretasikan dengan menggunakan kategori persentase penilaian validitas konstruk menurut Sugiyono (2007) adalah sebagai berikut: 76\%-100\% (Valid), 56\%-75\% (Cukup valid), $40 \% \quad-55 \%$ (Kurang valid), dan kurang dari $40 \%$ (Tidak valid). Pada aspek validitas isi, butir instrumen dikatakan valid jika ada catatan dari validator yang mengindikasikan bahwa butir-butir matriks, sebagaimana tercantum dalam Tabel 2 berikut. 
bahasa Indonesia, kalimat soal tidak mengandung arti ganda dan rumusan kalimat pertanyaan komutatif atau menggunakan bahasa sederhana bagi siswa. Tidak adanya catatan revisi dan saran perbaikan dari validator berarti validator tidak melihat adanya kesalahan tata bahasa pada naskah instrumen. Validitas psikometrik melewati tahap uji validitas, reliabilitas, tingkat kesukaran dan daya beda. Keterbacaan teks diukur melalui indeks Fog menggunakan rumus RGL.

Kategori miskonsepsi siswa
dianalisis menggunakan pedoman
pengkategorian miskonsepsi siswa dengan
sistem tabulasi yang dibuat Hasan et al. (1999). Jawaban masing-masing siswa dianalisis dengan menggunakan sistem tersebut untuk mengetahui konsepsi siswa terhadap masing-masing item tes ke dalam kategori tahu konsep (TK), tidak tahu konsep (TTK) dan miskonsepsi (MK). Dengan demikian, setiap siswa mendapat sejumlah TK, TTK dan MK untuk masingmasing konsep (sesuai jumlah item tes per konsep). Jumlah miskonsepsi per konsep dianalisis untuk ditempatkan pada kontinum tinggi, menengah dan rendah, dengan demikian, siswa dikategori menjadi tiga kelompok berdasarkan beban miskonsepsinya (jumlah miskonsepsinya): kelompok dengan kategori beban miskonsepsi tinggi $\left(\mathrm{MK}_{\mathrm{T}}\right)$, beban miskonsepsi rendah $\left(\mathrm{MK}_{\mathrm{R}}\right)$, dan beban miskonsepsi menengah $\left(\mathrm{MK}_{\mathrm{M}}\right)$.

Tabel 3. Hasil Penilaian Validitas Konstruk $\begin{array}{rrr}\text { Untuk } & \text { mengidentifikasi } & \text { terjadinya } \\ \text { miskonsepsi, } & \text { sekaligus } & \text { dapat }\end{array}$ membedakannya dengan tidak tahu konsep. Hasan et al (dalam Yuyu R. Tayubi, 2005) telah mengembangkan suatu metode identifikasi yang dikenal dengan istilah CRI (Certainty of Response Index), yang merupakan ukuran tingkat keyakinan/kepastian responden dalam menjawab setiap pertanyaan (soal) yang diberikan. CRI biasanya didasarkan pada suatu skala dan diberikan bersamaan dengan setiap jawaban suatu soal. Tingkat kepastian jawaban tercermin dalam skala CRI yang diberikan, CRI yang rendah menandakan ketidakyakinan konsep pada diri responden dalam menjawab suatu pertanyaan, dalam hal ini jawaban biasanya ditentukan atas dasar tebakan semata. Sebaliknya CRI yang tinggi mencerminkan keyakinan dan kepastian konsep yang tinggi pada diri responden dalam menjawab pertanyaan, dalam hal ini unsur tebakan sangat kecil. Seorang responden mengalami miskonsepsi atau tidak tahu konsep dapat dibedakan secara sederhana dengan cara membandingkan benar tidaknya jawaban suatu soal dengan tinggi rendahnya indeks kepastian jawaban (CRI) yang diberikannya untuk soal tersebut.

\section{HASIL DAN PEMBAHASAN}

Hasil penilaian ahli atas instrumen miskonsepsi kimia pada konsep struktur atom dilihat pada pada Tabel 3 berikut.

\begin{tabular}{|c|c|c|c|c|c|c|}
\hline \multirow{2}{*}{$\begin{array}{l}\text { Nomor } \\
\text { Soal }\end{array}$} & \multicolumn{3}{|c|}{ Validator } & \multirow{2}{*}{ Skor } & \multirow{2}{*}{$\begin{array}{c}\text { Persen Skor } \\
(\%) \\
\end{array}$} & \multirow{2}{*}{$\begin{array}{c}\text { Kriteria } \\
\text { Interpretasi Skor }\end{array}$} \\
\hline & 1 & 2 & 3 & & & \\
\hline 1 & 4 & 4 & 4 & 12 & 80 & Valid \\
\hline 2 & 4 & 4 & 4 & 12 & 80 & Valid \\
\hline 3 & 4 & 4 & 4 & 12 & 80 & Valid \\
\hline 4 & 4 & 4 & 4 & 12 & 80 & Valid \\
\hline 5 & 4 & 4 & 4 & 12 & 80 & Valid \\
\hline 6 & 4 & 4 & 4 & 12 & 80 & Valid \\
\hline
\end{tabular}




\begin{tabular}{|c|c|c|c|c|c|c|}
\hline \multirow{2}{*}{$\begin{array}{l}\text { Nomor } \\
\text { Soal }\end{array}$} & \multicolumn{3}{|c|}{ Validator } & \multirow{2}{*}{ Skor } & \multirow{2}{*}{$\begin{array}{c}\text { Persen Skor } \\
(\%)\end{array}$} & \multirow{2}{*}{$\begin{array}{c}\text { Kriteria } \\
\text { Interpretasi Skor }\end{array}$} \\
\hline & 1 & 2 & 3 & & & \\
\hline 7 & 1 & 3 & 4 & 8 & 53 & Cukup Valid \\
\hline 8 & 4 & 4 & 4 & 12 & 80 & Valid \\
\hline 9 & 4 & 4 & 4 & 12 & 80 & Valid \\
\hline 10 & 4 & 4 & 4 & 12 & 80 & Valid \\
\hline 11 & 4 & 4 & 4 & 12 & 80 & Valid \\
\hline 12 & 4 & 4 & 4 & 12 & 80 & Valid \\
\hline 13 & 4 & 4 & 4 & 12 & 80 & Valid \\
\hline 14 & 4 & 4 & 4 & 12 & 80 & Valid \\
\hline 15 & 4 & 4 & 4 & 12 & 80 & Valid \\
\hline 16 & 4 & 4 & 4 & 12 & 80 & Valid \\
\hline 17 & 1 & 3 & 4 & 8 & 53 & Cukup Valid \\
\hline 18 & 4 & 4 & 4 & 12 & 80 & Valid \\
\hline
\end{tabular}

Dari 18 butir soal instrumen miskonsepsi kimia, 16 butir atau 88,8\% dari total butir soal dinilai valid oleh ahli. Dua butir soal $(11,1 \%)$ mendapatkan penilaian cukup valid. Butir soal yang dinilai cukup valid tetap dapat digunakan untuk mengetahui miskonsepsi siswa. Validitas konstruk dari instrumen yang dikembangkan belum mencapai derajat kevalidan tertinggi (100\%). Peneliti telah melakukan perbaikan-perbaikan, khususnya pada butir soal nomor 7 dan nomor 17 agar instrumen yang dikembangkan memenuhi syarat validitas konstruk.

Hasil penilaian ahli terkait kebenaran isi atau kebenaran konsep-konsep yang terkandung dalam instrumen didasarkan kepada catatan tertulis yang diberikan ahli dapat dilaporkan bahwa sebagian besar validator berpendapat bahwa secara umum dari segi validitas isi item-item pada instrumen pendeteksi miskonsepsi siswa diketahui tidak ditemukan dalam jumlah besar fakta, konsep, prinsip yang salah. Dengan demikian dapat dikatakan instrumen yang dikembangkan telah memenuhi syarat validitas isi. Isi instrumen yang dikembangkan dapat digunakan mengungkap miskonsepsi siswa tentang atom karena item-item pertanyaan pada instrumen pendeteksi miskonsepsi siswa isinya relevan dengan atribut yang ingin diukur.

Tiga validator tidak menuliskan komentar dan saran perbaikan yang terlalu banyak terkait dengan isi instrumen pada penilaian instrumen miskonsepsi siswa. Peneliti berasumsi bahwa tidak adanya komentar dan saran perbaikan dari tiga validator ini berarti ketiga validator tidak melihat adanya kesalahan konsep atau kesalahan substansi secara umum isi dari naskah instrumen miskonsepsi siswa tersebut. Ada kritik dari salah satu validator untuk item nomor 7 dan item nomor 17 tentang konsep soal yang diberikan terlalu tinggi. Hasil kajian kepustakaan tidak terdapat kesalahan seperti yang dimaksudkan oleh validator sehingga instrumen pendeteksi miskonsepsi siswa dapat dinyatakan sudah memenuhi validitas isi. Kritik dari validator lain pada item nomor 1 terkait dengan indikator, item nomor 2 terkait dengan alternatif jawaban yang kurang tepat, item nomor 7 terkait dengan pilihan jawaban diusahakan tidak terlalu panjang. Peneliti telah melakukan perbaikan sesuai dengan kritik dan saran dari validator sehingga isi dari instrumen yang dibuat 
supaya tidak terdapat kesalahan konsep atau isi.

Hasil uji validitas untuk 18 butir instrumen miskonsepsi kimia ditetapkan melalui tahap uji coba instrumen. Berdasarkan data indeks validitas masingmasing soal dapat diberikan analisis bahwa dari 18 butir soal yang dibuat dinyatakan valid semua. Hasil uji reliabilitas untuk 18 Tabel 4. Hasil Analisis Tingkat Kesukaran dan Daya Beda Instrumen Miskonsepsi Kimia.

\begin{tabular}{cccccc}
\hline No & Item & TK & Kategori & Daya Beda & Kategori \\
\hline 1 & 1 & 0,568 & Sedang & 0,33 & Sedang \\
\hline 2 & 2 & 0,576 & Sedang & 0,44 & Baik \\
\hline 3 & 3 & 0,552 & Sedang & 0,42 & Baik \\
\hline 4 & 4 & 0,432 & Sedang & 0,38 & Sedang \\
\hline 5 & 5 & 0,504 & Sedang & 0,36 & Sedang \\
\hline 6 & 6 & 0,554 & Sedang & 0,41 & Baik \\
\hline 7 & 7 & 0,488 & Sedang & 0,42 & Baik \\
\hline 8 & 8 & 0,52 & Sedang & 0,49 & Baik \\
\hline 9 & 9 & 0,44 & Sedang & 0,57 & Baik \\
\hline 10 & 10 & 0,648 & Sedang & 0,42 & Baik \\
\hline 11 & 11 & 0,536 & Sedang & 0,33 & Sedang \\
\hline 12 & 12 & 0,472 & Sedang & 0,34 & Sedang \\
\hline 13 & 13 & 0,504 & Sedang & 0,31 & Sedang \\
\hline 14 & 14 & 0,40 & Sedang & 0,36 & Sedang \\
\hline 15 & 15 & 0,408 & Sedang & 0,71 & Baik \\
\hline 16 & 16 & 0,504 & Sedang & 0,33 & Sedang \\
\hline 17 & 17 & 0,56 & Sedang & 0,44 & Baik \\
\hline 18 & 18 & 0,616 & Sedang & 0,42 & Baik \\
\hline
\end{tabular}

Instrumen miskonsepsi kimia dibangun oleh butir-butir soal dengan nilai tingkat kesukaran berkategori sedang. Dari 18 butir soal yang dikembangkan memiliki dua kategori daya beda yakni kategori baik dan sedang. Butir-butir soal yang membangun Tabel 5. Hasil Analisis Miskonsepsi Siswa Tiap Individu

\begin{tabular}{ccccc}
\hline No & Kategori Miskonsepsi & Jumlah Siswa & Persentase & Rata-rata \\
\cline { 1 - 4 } 1 & Tinggi & 58 Orang & 58,58 & \\
\cline { 1 - 4 } 2 & Sedang & 35 Orang & 35,35 & \multirow{2}{*}{58,97} \\
\cline { 1 - 3 } & Rendah & 6 Orang & 6,06 & \\
\hline
\end{tabular}

Hasil analisis miskonsepsi siswa tiap individu dapat dilihat pada Tabel 6 berikut.

Tabel 6.Hasil Analisis Miskonsepsi Siswa Tiap Konsep.

\begin{tabular}{clcc}
\hline No & \multicolumn{1}{c}{ Konsep } & Persentase & Kategori \\
\hline 1 & Konfigurasi Elektron & $53,53 \%$ & Sedang \\
\hline 2 & Orbital & $66,66 \%$ & Tinggi \\
\hline 3 & Sub Kulit & $55,04 \%$ & Sedang \\
\hline 4 & Tingkat Energi & $59,92 \%$ & Sedang \\
\hline
\end{tabular}


Implementasi instrumen miskonsepsi kimia yang dilakukan di kelas XI MIPA SMAN 5 Kota Bima yang berjumlah 99 orang siswa. Analisis uji instrumen miskponsepsi kimia dianalisis pada dua jenis analisis yakni analisis miskonsepsi siswa secara individu dan analisis miskonsepsi siswa tiap konsep materi strukur atom. Hasil analisis miskonsepsi siswa secara individu didapatkan hasil bahwa siswa yang mengalami miskonsepsi tinggi berjumlah 58 orang, siswa yang mengalami miskonsepsi sedang berjumlah 35 orang dan siswa yang mengalami miskonsepsi rendah hanya berjumlah 6 orang. Jumlah rata-rata persentase miskonsepsi kimia secara individu didapatkan hasil sebesar 58,97\% dan ini menunjukkan bahwa miskonsepsi siswa tentang struktur atom berada pada kategori sedang

Hasil analisis miskonsepsi siswa tiap konsep struktur atom yang dikembangkan didapatkan hasil bahwa dari empat konsep yang terdiri dari konfigurasi elektron, orbital, sub kulit, dan tingkat energi berada pada kategori sedang dan kategori tinggi. Konsep yang dialami miskonsepsi dalam kategori tinggi terdapat pada konsep orbital, sedangkan konsep yang dialami miskonsepsi dalam kategori sedang terdapat pada konsep konfigurasi elektron, tingkat energi, dan sub kulit.

Inventaris kata-kata sulit dari instrumen miskonsepsi kimia dapat dilihat pada Tabel 7 berikut.

Tabel 7. Inventaris Kata-Kata Sulit dari Instrumen Miskonsepsi Kimia.

\begin{tabular}{ccc}
\hline No & Kata yang tidak dipahami & $\begin{array}{c}\text { Jumlah Responden yang Menuliskan Kata } \\
\text { Sulit Dipahami }\end{array}$ \\
\hline 1 & Tepi kontur & 2 \\
\hline 2 & Azimuth & 1 \\
\hline 3 & Probabilitas & 9 \\
\hline 4 & Kuantum & 1 \\
\hline 5 & Aturan Hund & 1 \\
\hline 6 & Eksklusi Pauli & 6 \\
\hline 7 & Orbital Penuh & 1 \\
\hline 8 & Awan elektron & 4 \\
\hline 9 & Orbital & 1 \\
\hline 10 & Kerapatan elektron & 1 \\
\hline 11 & Tingkat energi & 1 \\
\hline 12 & Kuantitas & 2 \\
\hline 13 & Unsur transisi netral & 2 \\
\hline & Jumlah & 32 \\
\hline
\end{tabular}

Hasil penilaian keterbacaan instrumen

miskonsepsi kimia dapat dilihat pada

Tabel 8 berikut.

Tabel 8. Hasil Penilaian Keterbacaan Instrumen Miskonsepsi Kimia.

\begin{tabular}{cccccc}
\hline $\begin{array}{c}\text { Jumlah } \\
\text { Kata }\end{array}$ & $\begin{array}{c}\text { Jumlah } \\
\text { Kalimat }\end{array}$ & $\begin{array}{c}\text { Rerata Jumlah } \\
\text { Kata Per Kalimat }\end{array}$ & $\begin{array}{c}\text { Persentase } \\
\text { Kata-kata Sulit }\end{array}$ & $\begin{array}{c}\text { Indeks Tingkat } \\
\text { Keterbacaan }\end{array}$ & Interprestasi \\
\hline 992 & 56 & 17,71 & $1,31 \%$ & 7,608 & $\begin{array}{c}\text { Mudah dipahami } \\
\text { siswa tingkat SMA }\end{array}$ \\
\hline
\end{tabular}


Penilaian keterbacaan instrumen miskonsepsi kimia dilakukan di kelas XI MIPA yang berjumlah 99 orang menggunakan indeks Fog. Hasil analisis penilaian keterbacaan instrumen miskonsepsi kimia dilihat dari jumlah kata sebanyak 992 kata, 56 kalimat, rata-rata jumlah kata per kalimat sebanyak 17,71, persentase kata-kata sulit sebesar 1,31\%, dan indeks tingkat keterbacaan sebesar 7,608. Beradasarkan indeks tingkat keterbacaan sebesar 8,38 mengindikasikan bahwa tingkat keterbacaan instrumen berada dalam kategori mudah dipahami siswa untuk tingkat SMA.

\section{KESIMPULAN}

Pengembangan

instrumen

miskonsepsi kimia pada konsep struktur atom telah memenuhi syarat validitas konstruk, validitas isi, validitas psikometrik, serta syarat keterbacaan.Instrumen miskonsepsi kimia yang dikembangkan dapat memberikan kategori miskonsepsi siswa dengan kategori miskonsepsi siswa tiap individu berada pada kategori sedang dengan ratarata 58,97\%, kategori miskonsepsi siswa tiap konsep berada pada kategori sedang untuk konsep konfigurasi elektron (53,53\%), sub kulit $(55,04 \%)$, tingkat energi $(59,92 \%)$ dan kategori tinggi hanya terdapat pada konsep orbital $(66,66 \%)$.

\section{SARAN}

????

\section{DAFTAR PUSTAKA}

Abosalem, Y.M. 2013. The Relationship Between the Learning Sty les of Students in Grades Five and Six and Their Held Misconceptions About Dividing Fractions Based on Kolb ${ }^{\text {ee }}$
Model." Thesis. Dubai: The British University.

Al-Balushi, S.M., Ambusaidi, A. K., AlShuaili, A.H., Taylor, N. (2012). "Omani twelfth grade students' most common misconceptions in chemistry". Internasional Council of Associations for Science Education. Vol.23, No.3, September 2012. Pp. 221-240

Dahar, R.W. 2011. Teori-teori Belajar \& Pembelajaran. Jakarta: Erlangga

Chi, M.T.H., De Leeuw, N., Chiu, M.H., Lavancher, C. 1994. Eliciting Self Explanations Improves Understanding. Cognitive Science. Vol 18. 1994. Pp. 439-477. University of Pittsburgh

Hasan, S., Bagayoko, D., Kelley, E. 1999. Misconceptions and certainty of Response Index (CRI). Department of Science and Mathematics Education, Southern University and A\&M College, Baton Rouge, LA 70813, USA

Horton, C. 2004. Student Alternative Conceptions in Chemistry. Modeling Instruction in High School Chemistry Action Research. Arizona State University.

Park, J.E. 2006. Student Perception and Conceptual Development As Represented By Student Mental Models of Atomic Structure. Dissertation. The Ohio State University. Diunduh

Pada 04 Desember 2015 dari https:/ letd.ohiolink.edu/rws etd/document/ get/osu1150442841/inline.

Punaji. 2015. Metode Penelitian Pendidikan \& Pengembangan. Jakarta: Prenadamedia Group

Sen, S. dan Yilmaz, A. 2012. The effect of learning sty les on students' misconceptions and selfefficacy for learning and performance. Procedia 
- Social and Behavioral Sciences, Vol. 46, Hal. 1482-1486.

Salirawati, D. Wiyarsih, A. 2012. Pengembangan Instrumen Pendeteksi Miskonsepsi Materi Ikatan Kimia Untuk Peserta Didik SMA. Artikel. FMIPA Univeristas Negeri Yogyakarta.

Sugiyono. 2013. Metode Penelitian Pendidikan. Bandung: Alfabeta
Suparno, Paul. 2005. Miskonsepsi \& Perubahan Konsep Fisika. Jakarta: PT. Grasindo

Yuyu R. Tayubi. 2005 Identifikasi Miskonsepsi Pada Konsep-Konsep Fisika Menggunakan Certainty of Response Index (CRI). Mimbar Pendidikan, No. 3/XXIV/2005. 